\title{
Food Preparations Used in Weaning Urban Bantu Infants
}

\author{
BY A. R. P. WALKER, DOROTHY C. FLETCHER, \\ EMMERENTIA S. P. STRYDOM AND MARIANNE ANDERSSON \\ Human Biochemistry Unit of the South African Institute for Medical Research, \\ fohannesburg and the South African Council for Scientific and Industrial Research
}

(Received 22 Fune 1954)

In South Africa, it is customary for Bantu mothers to feed their babies almost exclusively at the breast for from 6 to 9 months, and subsequently to feed them partly at the breast for a variable period, sometimes as long as 3 years. In urban centres, in contrast with rural areas, the position differs somewhat, for Bantu women are often employed in domestic service or factories. When such women become mothers, they often want to return to work as soon as possible after parturition. Occasionally, therefore, their babies are cared for by relatives, so that premature weaning occurs.

As is well known, the most critical period in the nutritional life of the Bantu commences with weaning. The occurrence of the crisis is ascribed to ignorance, to the limited ability to buy milk products or nutritionally satisfactory milk-substitute foods, and to the fact that the weaned child is not given preferential treatment, but has to compete for the available food with the older members of the family group (Brock \& Autret, 1952).

The commonness of undernutrition and malnutrition among Bantu children at weaning suggested to us that it would be of value to determine the composition of the food actually prepared by Bantu mothers for their children.

\section{EXPERIMENTAL}

Subjects and samples. In Johannesburg there are about half a million Bantu, of whom the majority dwell in townships south of the city. The region is served by Baragwanath Non-European Hospital which has $135^{\circ}$ beds. To obtain our main series of samples we took advantage of the fact that mothers seeking medical attention for themselves or their children usually prepare food to be given to the children while waiting in the out-patient department. The subjects whose feeds were sampled were selected at random, except that patients too ill to suck were not represented because their mothers had not brought food for them. Of this main series of subjects, twentyfour were under 6 months, thirteen were from 7 to 12 months, seven were from 13 to 18 months, and fourteen were from 19 to 24 months. Of the fifty-eight samples collected, fifty-three were from bottles; five samples of thicker consistency were taken from other containers such as pans or tins. From four to eight samples were collected on one morning each week.

A smaller series of nineteen samples was obtained by a municipal health visitor when calling at Bantu homes. Of the child consumers, seven were from 7 to 12 months, 
and twelve from 13 to 18 months. Twelve of the samples were from bottles; the remaining seven, which were of thicker consistency, were taken from cooking pots.

The preparations given in feeding bottles were classified as:

Cereal paps, mainly of maize, prepared with or without some milk.

Proprietary foods containing cereals and dried milk, made up with or without milk.

Proprietary dried-milk products prepared with water only.

Miscellaneous mixtures.

The twelve samples given with a spoon were all thick cereal paps.

Methods. Total solids, ash, and protein were estimated by methods described by McCance \& Shipp (1933) and McCance, Widdowson \& Shackleton (1936). Fat was estimated by the Röse-Gottlieb method, with occasional checks by the method of Werner \& Schmidt, both as outlined by Cox (1950).

\section{RESULTS AND DISCUSSION}

The results, which include mean values, with the standard deviation and range, for the percentage of the chief constituents in the foods analysed are set out in Table $I$.

The samples collected at the out-patient department and in the homes were found to conform in their mean composition and range of constituents, so that the values for all the samples could be assembled in the same table. The uniformity of composition showed that the samples collected at Baragwanath Hospital could be taken as approximately representative of food prepared for the children at home.

The investigation showed that, in general, food mixtures were too much diluted. Except for the thick cereal paps given to the older children, the mixtures were almost invariably inadequate in calories, and the thin cereal paps, the proprietary cereal and dried-milk foods, and the miscellaneous foods were usually too low in protein concentration. These observations are in harmony with the fact that in Johannesburg more than half the patients in wards for children up to 2 years old are suffering from obvious malnutrition or undernutrition (Kahn, 1954).

Apart from poverty and ignorance we have come across another reason why food mixtures are too much diluted. A mixture prepared wholly or largely from cereal products and made up to fulfil calorie requirements is a gruel too thick to be consumed from a bottle. Bantu mothers face the difficulty by making the mixture too weak, by cooking it lightly to keep it thin, or by grossly enlarging the hole in the teat. Quite apart, therefore, from the nutritive inadequacy of a cereal-pap diet, it is virtually impossible for infants to make satisfactory progress on foods such as we have analysed.

The errors in preparation, which we have demonstrated, cannot, however, all be attributed to the ignorance or other failings of the Bantu mothers. We have obtained samples of all the types of commercial baby foods available in Johannesburg, and prepared feeds strictly according to the instructions on the label. We found that individual level tablespoons or other measures of powder differed in amount by as much as $10 \%$. Corresponding differences when measuring water amounted to about $30 \%$, and the amount of total solids varied by as much as $20 \%$. Obviously, if such differences occur in preparations made in the laboratory, larger differences in mixtures made even by European mothers, let alone Bantu mothers, are only to be expected. 


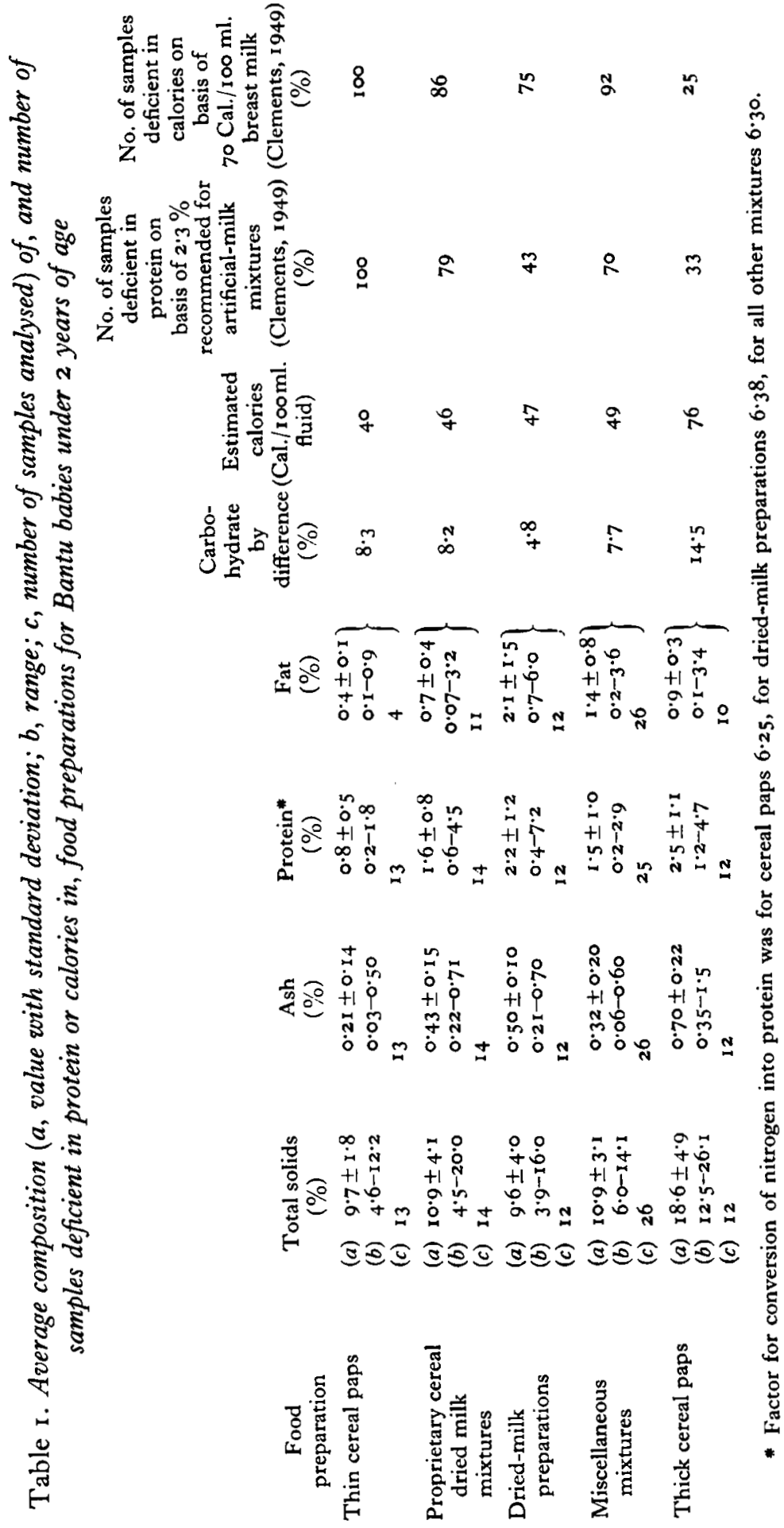


In a recently published paper Hytten (I954) reported the analysis of 100 artificial-milk mixtures prepared by Aberdeen mothers for their babies; seventy-eight of the samples were found to be inadequate calorically. Among white children, serious errors in food preparation and consumption would in time be reflected in the child's clinical state, and before long medical advice would be sought. With the Bantu the position is different, for a nutritional set-back at weaning is taken almost for granted, and a child can become very ill before the regimen is changed or the child brought to hospital. In the excellent clinical studies of Dean (1953) with milk-substitute foods, the preparations given to the children were closely controlled. What we have been observing is the uncontrolled side. If the observations we have made on the Witwatersrand are representative of other similar areas, the outlook is depressing, for it would seem that no matter what excellent foods are made available, their effectiveness will be reduced, and their nutritive value remain suspect, until they are correctly prepared for consumption. It is disturbing also to realize that such a state of affairs obtains, in spite of the bulk of urban Bantu women being literate, and in spite of a most determined campaign of nutritional instruction by paediatricians, clinic medical officers, and health and social workers.

\section{SUMMARY}

I. Among the young children of urban South African Bantu, undernutrition and malnutrition are very common at and after weaning.

2. The diet of children under 2 years of age was studied. Fifty-eight samples of food were taken from the bottles or other containers brought by mothers for their children when waiting in the out-patient clinic of the Baragwanath Hospital in Johannesburg, and rgi samples were taken in the home in Johannesburg.

3. The food mixtures included cereal paps, proprietary mixtures of cereals and dried milk, and preparations of dried milk.

4. Samples of the foods were analysed for total solids, protein, fat and ash.

5. It was found that a great many of the samples were too highly diluted so that the concentration of protein and calories was so low that the child could not make satisfactory progress.

6. The numerous serious causes of over-dilution are discussed, and it is stressed that, even apart from them, the instructions given with commercial infant foods often permit the total solids in the liquid food to vary by as much as $30 \%$.

This paper is published with the permission of the South African Council for Scientific and Industrial Research.

\section{REFERENCES}

Brock, J. F. \& Autret, M. (1952). F.A.O. nutr. Stud. no. 8.

Clements, F. W. (1949). Infant Nutrition. Bristol: John Wright and Sons.

Cox, H. E. (1950). Chemical Analysis of Foods, $4^{\text {th }}$ ed. London: J. and A. Churchill.

Dean, R. F. A. (1953). Spec. Rep. Ser. med. Res. Coun., Lond., no. 279.

Hytten, F. E. (1954). Proc. Nutr. Soc. $\mathrm{r}_{3}$, iv.

Kahn, E. (1954). Private communication.

McCance, R. A. \& Shipp, H. L. (1933). Spec. Rep. Ser. med. Res. Coun., Lond., no. 187.

McCance, R. A., Widdowson, E. M. \& Shackleton, L. R. B. (1936). Spec. Rep. Ser. med.

Res. Coun., Lond., no. $2 \mathrm{I} 3$. 